\title{
Going green: strategic evaluation of green ICT adoption in the textile industry by using bipolar fuzzy MULTIMOORA method
}

DOI: 10.35530/IT.072.01.1841

\section{ABSTRACT - REZUMAT \\ Going green: strategic evaluation of green ICT adoption in the textile industry by using bipolar fuzzy MULTIMOORA method}

\begin{abstract}
The widespread use of information and communication technologies in all fields has a direct impact on the way the world is viewed. In today's competitive international business environment, companies are increasingly investing in the search for new ideas and approaches in production. The use of information and communication technologies (ICT) is increasingly gaining in importance, especially in the situation of a dynamic market and increasingly demanding consumers. Today's business of contemporary organizations is not conceivable without the support of modern ICT systems. Therefore ICT has a great influence on modern society because the ways in which information and data are exchanged are higher than ever. Green information and communication technologies as one area that is new and in development tend to establish a balance between these technologies and the environment. Adoption of green information and communication technologies is not an easy task and is often related to certain limitations. Therefore, the aim of the paper is a strategic evaluation of green ICT and their implementation in the textile industry by using newly-developed bipolar fuzzy MULTIMOORA method. Effectiveness and efficacy of the proposed approach is demonstrated in the conducted illustrative case study.
\end{abstract}

Keywords: Green ICT, ICT, textile industry, MCDM, bipolar fuzzy MULTIMOORA method

Adoptarea metodei ecologice: evaluarea strategică a adoptării eco-TIC în industria textilă prin utilizarea metodei bipolare fuzzy MULTIMOORA

Utilizarea pe scară largă a tehnologiilor informației și comunicațiilor în toate domeniile are un impact direct asupra modului în care lumea este privită. În mediul de afaceri internațional competitiv de astăzi, companiile investesc din ce în ce mai mult în căutarea de noi idei și abordări în domeniul producției. Utilizarea tehnologiilor informației și comunicațiilor (TIC) capătă din ce în ce mai multă importanță, în special în situația unei piețe dinamice și a consumatorilor din ce în ce mai pretențioși. Afacerile de astăzi ale organizațiilor nu sunt concepute fără sprijinul sistemelor moderne TIC. Prin urmare, TIC au o mare influență asupra societății moderne, deoarece modalitățile prin care sunt schimbate informații și date sunt mai avansate ca niciodată. Eco-TIC, ca domeniu nou și în curs de dezvoltare, tinde să stabilească un echilibru între aceste tehnologii și mediu. Adoptarea eco-TIC nu este o sarcină ușoară și este adesea legată de anumite limitări. Prin urmare, scopul lucrării este o evaluare strategică a eco-TIC și implementarea acestuia în industria textilă, utilizând metoda bipolară fuzzy MULTIMOORA, dezvoltată recent. Eficacitatea abordării propuse este demonstrată în studiul de caz realizat.

Cuvinte-cheie: eco-TIC, TIC, industria textilă, MCDM, metoda bipolară fuzzy MULTIMOORA

\section{INTRODUCTION}

One of the biggest, oldest and most commercialized industries in the world is the textile industry. The textile industry is an important branch of the manufacturing industry and is of great importance for the economy of a country. Today, the textile industry is one of the most globalized industries. Accordingly, the prerequisite for success is the continuous monitoring of current market trends in terms of standards, raw materials and technical equipment of production [1]. The textile industry, as a very important industrial area is technically and technologically very demanding.
The opportunity for the growth of textile production can be exploited by those managers and organizations that are ready to change their business paradigms and that are open to creating changes and introducing new information and communication technologies (ICT) in production. It is emphasized that new technologies in the textile industry are developed in order to improve textile and clothing manufacturing and trade. Some of the goals which new technologies and above ICT should bring are: "1. providing response to new fashion trends; 2. ensuring the efficiency and effectiveness of mass 
production through the application of ICT (computeraided design) and 3 . adaptation to increasingly sophisticated customers (selling online through web platforms, offering added value through quality or price, ensuring a long term relationship etc.)" [2].

In today's competitive business environment, companies are increasingly investing in the search for new ways and approaches in production. The use of information and communication technologies plays a vital role and is increasingly gaining in importance, especially in the situation of a dynamic market and increasingly demanding consumers. Today's business of contemporary organizations is not conceivable without the support of modern ICT systems. Therefore ICT has a great influence on modern society because the ways in which information and data are exchanged are higher than ever [3].

The role of ICT is becoming increasingly important in all aspects of life (education, work, entertainment, health, etc.). Davison [4] point out that the term is used interchangeably in order to cover the full spectrum of existing and potential ICT that are used, including computers, personal communication devices, digital video and sound systems, email, the Internet, etc. ICT is mainly related to the technologies that are used for accessing, collecting, manipulating and presenting or transmitting the information. ICT technologies may include hardware (e.g. computers and other devices); software applications; and connectivity (e.g. Internet access, local area network infrastructure, video conferencing). Exactly what is most important about ICT is the increasing convergence of computer-based, multimedia and communication technologies, as well as the rapid rate of change that characterizes technologies and their use $[5,6]$. ICT is most commonly related to two main components: information technology (IT) and communication technology (CT). IT mostly involves computer hardware and software, while CT is related to Internet communication [7]. ICT is a broader concept that includes communication devices, various services, video conferencing, online learning, etc., in order to provide users with access, storage, transmission and manipulation of information [8].

Veljović et al. [9] point out that the most important components of information and communication technologies are computers. At the same time, the application and development of digital communications enabled an easy, fast, efficient and inexpensive way of exchanging information. Therefore, ICTs include a diverse set of technology tools that are used to identify and organize data and information. Murray [10] states that ICT is expanding the concept of information technology in which particularly is highlighted the role and importance of the integration of communications, telecommunications and computers, as well as the necessary software, storage and audiovisual system that gives users the ability to access, store and further manipulate information.

Today's business of contemporary organizations is not conceivable without the support of modern ICT systems. Therefore ICT has a great influence on modern society because the ways in which information and data are exchanged are higher than ever. Green information and communication technologies as one area that is new and in development tend to establish a balance between these technologies and the environment. Also, as Din et al. [11] point out, green ICT, as a concept was introduced with the aim to support the implementation of the green environment, i.e. is aimed at conserving energy as one essential domain.

There is no universal definition of green information and communication technologies. ReimsbachKounatze [12] emphasizes that the "green ICT is about the study and practice of using computing resources in an efficient, effective and economical way". Sarkis and Zhu [13] states that "green ICT refers more to the hardware and other infrastructure that can be better managed and designed from an environmental perspective". Andreopoulou [14] states that green ICT "are ICT tools, certain services and technologies that in combination with green practices and green behavior contribute not only to the protection of the environment but also to the enhancement of the quality of life". Radu [15] emphasizes that coherence between ICT and the environment is relatively new and that the using of environmental criteria is often referred to as green ICT.

Adoption of green information and communication technologies is not an easy task and is often related to certain limitations. The process of evaluation of green ICT can be a challenging task. However, problem of green ICT evaluation can be easily solved by using multiple-criteria decision-making methods.

Decision making is a process that is constantly happening all around us [16]. In real-world situations, decision-making is most often made on the basis of the existence of a number of criteria, which are often conflicting; therefore, for solving such problems using of multiple-criteria decision-making methods (MCDM) is an option. MCDM enables the selection of a suitable alternative from a finite set of alternatives while respecting the values of the criterion attributes, i.e. it enables decision-making in the presence of multiple, often conflicting criteria [17-22]. Ishizaka and Nemery [23] indicate the growing use of MCDM methods because these methods primarily enable better decision-making and adoption of long-term and sustainable solutions.

The extremely rapid development of the MCDM field has also caused the creation of a wide range of MCDM methods, which have been applied so far in solving different types of problems. Some of the prominent and most applied methods are: SAW, AHP, ELECTRE, PROMETHEE, ANP, VIKOR, COPRAS and so on [24-26]. Also, it is important to note that for the needs of solving more complex problems, a whole generation of new MCDM methods and approaches have been proposed, such as: MOORA, MULTIMOORA, WASPAS, SWARA, ARAS, ARCAS, PIPRECIA, MAIRCA, EDAS, CODAS and so on $[27,28]$.

industuoia tertillă 
Based on the foregoing stated, the aim of the paper is the strategic evaluation of green information and communication technologies adoption in the textile industry by using newly-developed bipolar fuzzy MULTIMOORA method. Therefore, in order to present an MCDM for the purpose of green ICT evaluation, the remainder of the paper is organized into four sections. In Section 1, a literature review is provided. Section 2 contains the presentation of the applied methodology. A case study is introduced in Section 3, which is followed by the section presenting the conclusion.

\section{THE COMPUTATIONAL PROCEDURE OF THE SVBFN-MULTIMOORA METHOD}

Extension of the MULTIMOORA method based on Single-Valued Bipolar Fuzzy Numbers is proposed by Stanujkic et al. [29]. Brauers [30] initially proposed the well-known MOORA method, somewhat later Brauers and Zavadskas [31] have proposed MULTIMOORA method. So far, MULTIMOORA method has been applied for solving various problems in different fields, such as: economy [31-34]; personnel selection [35-38]; supplier selection [39, 40]; information and communication technologies [41, 42], robotics [43], comminution circuit design selection [44], assessment of the energy storage technologies [45], and so on. The computational procedure of the SVBFN-MULTIMOORA method can be expressed as follows [29]:

Step 1. Evaluation of the alternatives in relation to the selected set of criteria for each decision-maker DM. In this step evaluation could be easily performed by using the nine-point Liker scale that is proposed by Stanujkic [29].

Step 2. Determination of the importance of the evaluated criteria for each DM.

Step 3. Determination of the group decision matrix, as it is proposed in [29].

Step 4. Determination of the group weights of the criteria, as follows:

$$
w_{j}=\sum_{k=1}^{K} w_{j}^{k}
$$

where $w_{j}$ denotes the weight of the criterion $j$, and $w_{j}^{k}$ denotes the weight of the criterion $j$ obtained from the $\mathrm{DM} k$.

Step 5. Determination of the significance of the evaluated alternatives based on the RS approach. This step can be explained through the following substeeps:

Step 5.1. Determination of the impact of the benefit and cost criteria to the importance of each alternative, as follows:

$$
\begin{aligned}
& Y_{i}^{+}=\left(1-\prod_{j \in \Omega_{\max }}^{n}\left(1-r_{i j}\right)^{w_{j}},-\left(1-\prod_{j \in \Omega_{\max }}^{n}\left(1-\left(-r_{i j}\right)\right)^{w_{j}}\right)\right) \\
& Y_{i}^{-}=\left(1-\prod_{j \in \Omega_{\max }}^{n}\left(1-r_{i j}\right)^{w_{j}},-\left(1-\prod_{j \in \Omega_{\max }}^{n}\left(1-\left(-r_{i j}\right)\right)^{w_{j}}\right)\right)
\end{aligned}
$$

where $Y_{i}^{+}$and $Y_{i}^{-}$denote the importance of the alternative $i$ obtained on the basis of the benefit and cost criteria, respectively; $Y_{i}^{+}$and $Y_{i}^{-}$are SVBFNs.

It is evident that $A_{w}$ operator is used to calculate the impact of the benefit and cost criteria.

Step. 5.2. Transformation of the $Y_{i}^{+}$and $Y_{i}^{-}$into crisp values by using the Score Function, as follows:

$$
\begin{gathered}
y_{i}^{+}=s\left(Y_{i}^{+}\right) \\
y_{i}^{-}=s\left(Y_{i}^{-}\right)
\end{gathered}
$$

Step 5.3. Calculation of the overall importance for each alternative, as follows:

$$
y_{i}=y_{i}^{+}-y_{i}^{-}
$$

Step 6. Determination of the significance of the evaluated alternatives based on the RP approach. This step can be explained through the following substeeps:

Step 6.1. Determination of the reference point (RP). The coordinates on the bipolar fuzzy reference point $r^{*}=\left\{r_{1}^{*}, r_{2}^{*}, \ldots, r_{n}^{*}\right\}$ can be determined as follows:

$$
\begin{aligned}
r^{*}= & \left\{\left(<\max _{i} r_{i j}, \min _{i} r_{i j}>\mid j \in \Omega_{\max }\right),\right. \\
& \left.\left(<\min _{i} r_{i j}, \max _{i} r_{i j}>\mid j \in \Omega_{\min }\right)\right\}
\end{aligned}
$$

where $r_{j}^{*}$ denotes the coordinate $j$ of the reference point.

Step 6.2. Determination of the maximum distance from each alternative to all the coordinates of the reference point as follows:

$$
d_{i j}^{\max }=d_{\max }\left(r_{i j}, r_{j}^{*}\right) w_{j}
$$

where $d_{i j}^{\max }$ denotes the maximum distance of the alternative $i$ to the criterion $j$.

Step 6.3. Determination of the maximum distance of each alternative, as follows:

$$
d_{i}^{\max }=\max _{j} d_{i j}^{\max }
$$

where $d_{i}^{\max }$ denotes the maximum distance of the alternative $i$.

Step 7. Determination of the significance of the evaluated alternatives based on the FMF:

Step 7.1. Calculation of the utility obtained based on the benefit $U_{i}^{+}$and cost $U_{i}^{-}$criteria, for each alternative, as follows:

$$
\begin{aligned}
& U_{i}^{+}=\left(\prod_{j \in \Omega_{\max }}^{n}\left(r_{i j}\right)^{w_{j}},-\prod_{j \in \Omega_{\max }}^{n}\left(-r_{i j}\right)^{w_{j}}\right) \\
& U_{i}^{-}=\left(\prod_{j \in \Omega_{\min }}^{n}\left(r_{i j}\right)^{w_{j}},-\prod_{j \in \Omega_{\min }}^{n}\left(-r_{i j}\right)^{w_{j}}\right)
\end{aligned}
$$

where and are SVBFNs.

Step 7.2. Transformation of the and into crisp values by using the Score Function, as follows:

$$
\begin{aligned}
& u_{i}^{+}=s\left(U_{i}^{+}\right) \\
& u_{i}^{-}=s\left(U_{i}^{-}\right)
\end{aligned}
$$


Step 7.3. Determination of the overall utility for each alternative, as follows:

$$
u_{i}=\frac{u_{i}^{+}}{u_{i}^{-}}
$$

In the case when evaluation is made only on the basis of benefit criteria Eq. (14) is as follows:

$$
u_{i}=u_{i}^{+}
$$

Step 8. Determination of the final ranking order of the alternatives by using theory of dominance.

\section{A NUMERICAL CASE STUDY}

In this part of the paper, a numerical case study is considered in order to highlight the proposed methodology. As stated before, there is a tendency towards using green ICT. A textile company has decided to introduce green ICT. For this reason, a team consisted of $3 \mathrm{DMs}$ was formed in order to evaluate four alternatives designated as $A_{1}, A_{2}, A_{3}, A_{4}$. Based on carefully literature review [49-50], a total number of 5 evaluation criteria were selected: $C_{1}$ Economic and energy efficiency; $C_{2}-$ Eco-friendliness; $C_{3}$-Technology evolution; $C_{4}-$ Improved systems performance and use; $C_{5}$ - Overall impact of green ICT on the organization.

The ratings of the evaluated alternatives in the form of SVBFNs for the three decision-makers are shown in tables 1-3.

The group decision matrix is shown in table 4.

The group weights obtained from the three DMs by applying the PIPRECIA method [48] and by using equation (1) are accounted for in table 5.

Table 1

\begin{tabular}{|c|c|c|c|c|c|}
\hline \multicolumn{7}{|c|}{ THE RATINGS OBTAINED FROM THE FIRST OF THE THREE DMS } \\
\hline Alternatives & $\mathbf{C}_{\mathbf{1}}$ & $\mathbf{C}_{\mathbf{2}}$ & $\mathbf{C}_{\mathbf{3}}$ & $\mathbf{C}_{\mathbf{4}}$ & $\mathbf{C}_{\mathbf{5}}$ \\
\hline $\mathrm{A}_{1}$ & $<0.80,-0.20>$ & $<0.80,-0.10>$ & $<0.70,-0.30>$ & $<0.80,-0.30>$ & $<0.50,-0.20>$ \\
\hline $\mathrm{A}_{2}$ & $<0.40,-0.50>$ & $<0.30,-0.30>$ & $<0.40,-0.40>$ & $<0.30,-0.30>$ & $<0.20,-0.30>$ \\
\hline $\mathrm{A}_{3}$ & $<0.50,-0.30>$ & $<0.40,-0.30>$ & $<0.40,0.10>$ & $<0.50,-0.30>$ & $<0.60,-0.50>$ \\
\hline $\mathrm{A}_{4}$ & $<0.90,-0.10>$ & $<0.70,-0.10>$ & $<0.70,0.10>$ & $<0.80,-0.30>$ & $<0.70,-0.40>$ \\
\hline
\end{tabular}

\begin{tabular}{|c|c|c|c|c|c|}
\hline \multicolumn{7}{|c|}{ THE RATINGS OBTAINED FROM THE SECOND OF THE THREE DMS } \\
\hline Alternatives & $\mathbf{C}_{\mathbf{1}}$ & $\mathbf{C}_{\mathbf{2}}$ & $\mathbf{C}_{\mathbf{3}}$ & $\mathbf{C}_{\mathbf{4}}$ & $\mathbf{C}_{\mathbf{5}}$ \\
\hline $\mathrm{A}_{1}$ & $<1.00,-0.10>$ & $<0.90,-0.20>$ & $<0.80,-0.20>$ & $<0.60,-0.10>$ & $<0.70,-0.10>$ \\
\hline $\mathrm{A}_{2}$ & $<0.60,-0.30>$ & $<0.80,-0.40>$ & $<0.70,-0.20>$ & $<0.50,-0.30>$ & $<0.60,-0.30>$ \\
\hline $\mathrm{A}_{3}$ & $<0.70,-0.30>$ & $<0.50,-0.30>$ & $<0.60,-0.20>$ & $<0.80,-0.20>$ & $<0.50,-0.30>$ \\
\hline $\mathrm{A}_{4}$ & $<1.00,-0.10>$ & $<1.00,-0.10>$ & $<0.70,-0.20>$ & $<0.80,-0.20>$ & $<0.80,-0.20>$ \\
\hline
\end{tabular}

THE RATINGS OBTAINED FROM THE THIRD OF THE THREE DMS

\begin{tabular}{|c|c|c|c|c|c|}
\hline Alternatives & $\mathbf{C}_{\mathbf{1}}$ & $\mathbf{C}_{\mathbf{2}}$ & $\mathbf{C}_{\mathbf{3}}$ & $\mathbf{C}_{\mathbf{4}}$ & $\mathbf{C}_{\mathbf{5}}$ \\
\hline $\mathrm{A}_{1}$ & $<1.00,-0.20>$ & $<0.90,-0.20>$ & $<0.80,-0.20>$ & $<0.70,-0.20>$ & $<0.60,-0.20>$ \\
\hline $\mathrm{A}_{2}$ & $<0.50,-0.40>$ & $<0.40,-0.20>$ & $<0.50,-0.20>$ & $<0.70,-0.30>$ & $<0.50,-0.30>$ \\
\hline $\mathrm{A}_{3}$ & $<0.40,-0.20>$ & $<0.50,-0.20>$ & $<0.50,-0.10>$ & $<0.80,-0.30>$ & $<0.60,-0.30>$ \\
\hline $\mathrm{A}_{4}$ & $<1.00,-0.20>$ & $<1.00,-0.10>$ & $<0.60,-0.10>$ & $<0.70,-0.20>$ & $<0.60,-0.30>$ \\
\hline
\end{tabular}

\begin{tabular}{|c|c|c|c|c|c|}
\hline \multicolumn{7}{|c|}{ THE GROUP DECISION-MAKING MATRIX } \\
\hline Alternatives & $\mathbf{C}_{\mathbf{1}}$ & $\mathbf{C}_{\mathbf{2}}$ & $\mathbf{C}_{\mathbf{3}}$ & $\mathbf{C}_{\mathbf{4}}$ & $\mathbf{C}_{\mathbf{5}}$ \\
\hline $\mathrm{A}_{1}$ & $<1.00,-0.16>$ & $<0.87,-0.16>$ & $<0.77,-0.23>$ & $<0.71,-0.19>$ & $<0.60,-0.16>$ \\
\hline $\mathrm{A}_{2}$ & $<0.50,-0.40>$ & $<0.56,-0.29>$ & $<0.55,-0.26>$ & $<0.52,-0.30>$ & $<0.45,-0.30>$ \\
\hline $\mathrm{A}_{3}$ & $<0.55,-0.27>$ & $<0.46,-0.27>$ & $<0.50,-0.13>$ & $<0.72,-027>$ & $<0.56,-0.36>$ \\
\hline $\mathrm{A}_{4}$ & $<1.00,-0.13>$ & $<1.00,-0.10>$ & $<0.67,-0.13>$ & $<0.77,-0.23>$ & $<0.71,-0.09>$ \\
\hline
\end{tabular}


Table 5

\begin{tabular}{|c|c|c|c|c|}
\hline \multicolumn{5}{|c|}{ THE GROUP CRITERIA WEIGHTS } \\
\hline Criteria & $\boldsymbol{w}_{\boldsymbol{j}}^{\mathbf{1}}$ & $\boldsymbol{w}_{\boldsymbol{j}}^{\mathbf{2}}$ & $\boldsymbol{w}_{\boldsymbol{j}}^{\mathbf{3}}$ & $\boldsymbol{w}_{\boldsymbol{j}}$ \\
\hline $\mathrm{C}_{1}$ & 0.24 & 0.23 & 0.27 & 0.25 \\
\hline $\mathrm{C}_{2}$ & 0.19 & 0.25 & 0.20 & 0.21 \\
\hline $\mathrm{C}_{3}$ & 0.21 & 0.23 & 0.20 & 0.21 \\
\hline $\mathrm{C}_{4}$ & 0.18 & 0.18 & 0.17 & 0.18 \\
\hline $\mathrm{C}_{5}$ & 0.18 & 0.12 & 0.15 & 0.15 \\
\hline \multicolumn{5}{|c|}{ Total } \\
\hline
\end{tabular}

Based on the ratings from table 4 and the weights from table 5 , the overall significance, the maximum distance to the RS and the overall utility are calculated for each alternative in the next step. The overall significances accounted for in table 6 , are calculated by applying equations (2)-(6).

Thereafter, the RP is determined by using equation (7). The maximum distances to the RP accounted for in table 7 are determined by using equation (8) and equation (9).

The overall utility shown in table 8 is calculated by applying equations (10)-(14).

Taking into consideration ranking orders shown in tables 6, 7 and 8, the most appropriate alternative is determined by the theory of dominance, as is shown in figure 1.

As can be seen from figure 1, the alternative denoted as $A_{4}$ is the most appropriate in the terms of evaluated criteria.

Additionally, to verify the reliability of the proposed approach and to confirm ranking orders obtained by using the SVBFN-MULTIMOORA method, a sensitivity analysis was conducted with the comparison of the ranking results obtained by using of SVBFNMULTIMOORA method with 2 well-known and proven MCDM methods (TOPSIS and SAW). The obtained results of the conducted sensitivity analysis are shown in figure 2 and table 9.

It can also be concluded from table 9 that the small inconsistency in the ranking orders of the considered alternatives obtained by applying the TOPSIS

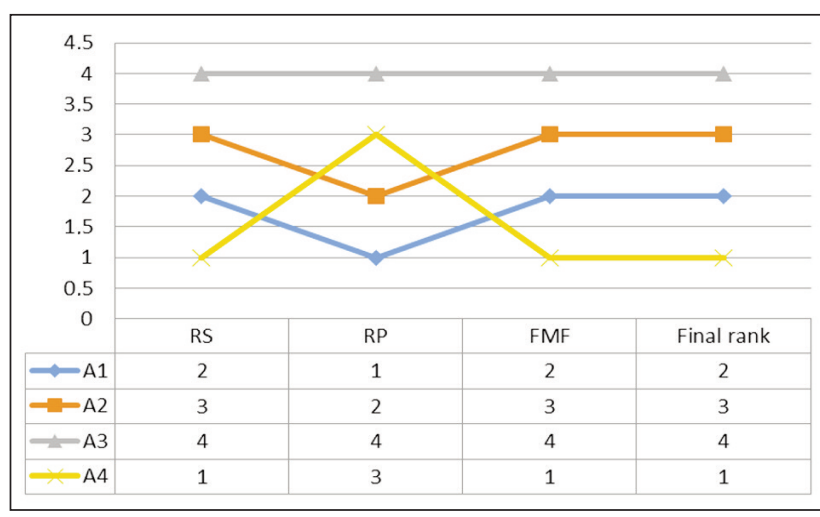

Fig. 1. The final ranking order of the considered alternatives by using theory of dominance

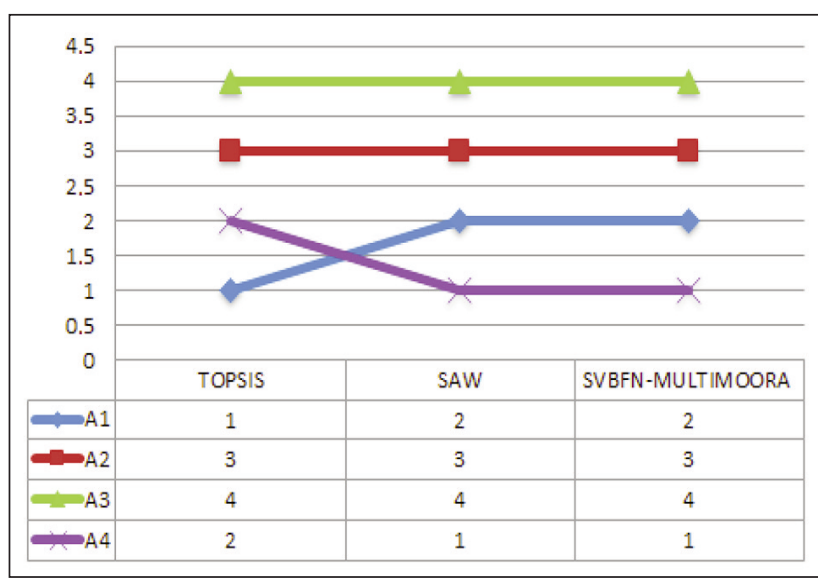

Fig. 2. Results of the sensitivity analysis

\begin{tabular}{|c|c|c|c|c|c|c|}
\hline \multicolumn{7}{|c|}{ THE OVERALL SIGNIFICANCES OF THE CONSIDERED ALTERNATIVES } \\
\hline Alternatives & $\boldsymbol{Y}_{\boldsymbol{i}}^{+}$ & $\boldsymbol{Y}_{\boldsymbol{i}}^{-}$ & $\boldsymbol{y}_{\boldsymbol{i}}^{+}$ & $\boldsymbol{y}_{\boldsymbol{i}}^{-}$ & $\boldsymbol{y}_{\boldsymbol{i}}$ & Rank \\
\hline $\mathrm{A}_{1}$ & $<1.00,-0.13>$ & $<0.33,-0.07>$ & 0.94 & 0.63 & 0.30 & 2 \\
\hline $\mathrm{A}_{2}$ & $<0.40,-0.23>$ & $<0.22,-0.12>$ & 0.59 & 0.55 & 0.04 & 3 \\
\hline $\mathrm{A}_{3}$ & $<0.38,-0.16>$ & $<0.33,-0.13>$ & 0.61 & 0.60 & 0.01 & 4 \\
\hline $\mathrm{A}_{4}$ & $<1.00,-0.08>$ & $<0.39,-0.10>$ & 0.96 & 0.64 & 0.31 & 1 \\
\hline
\end{tabular}

THE RATINGS OF THE ALTERNATIVES OBTAINED BASED ON THE RP APPROACH

\begin{tabular}{|c|c|c|c|c|c|c|c|}
\hline Alternatives & $\mathbf{C}_{\mathbf{1}}$ & $\mathbf{C}_{\mathbf{2}}$ & $\mathbf{C}_{\mathbf{3}}$ & $\mathbf{C}_{\mathbf{4}}$ & $\mathbf{C}_{\mathbf{5}}$ & $\boldsymbol{d}_{\boldsymbol{i}}$ & Rank \\
\hline $\mathrm{A}_{1}$ & 0.12 & 0.13 & 0.01 & 0.09 & 0.08 & 0.01 & 1 \\
\hline $\mathrm{A}_{2}$ & 0.25 & 0.22 & 0.11 & 0.06 & 0.07 & 0.06 & 2 \\
\hline $\mathrm{A}_{3}$ & 0.29 & 0.28 & 0.20 & 0.14 & 0.16 & 0.14 & 4 \\
\hline $\mathrm{A}_{4}$ & 0.13 & 0.10 & 0.11 & 0.15 & 0.19 & 0.10 & 3 \\
\hline
\end{tabular}




\begin{tabular}{|c|c|c|c|c|c|c|c|c|}
\hline \multicolumn{8}{|c|}{ THE OVERALL UTILITY OF THE CONSIDERED ALTERNATIVES } \\
\hline Alternatives & $\boldsymbol{U}_{\boldsymbol{i}}^{+}$ & $\boldsymbol{U}_{\boldsymbol{i}}^{-}$ & $\boldsymbol{u}_{\boldsymbol{i}}^{+}$ & $\boldsymbol{u}_{\boldsymbol{i}}^{-}$ & $\boldsymbol{u}_{\boldsymbol{i}}$ & \multicolumn{4}{c|}{ Rank } \\
\hline$A_{1}$ & $<0.92,-0.32>$ & $<0.86,-0.53>$ & 0.80 & 0.67 & 1.20 & 2 \\
\hline$A_{2}$ & $<0.66,-0.46>$ & $<0.77,-0.65>$ & 0.60 & 0.56 & 1.07 & 3 \\
\hline$A_{3}$ & $<0.63,-0.35>$ & $<0.86,-0.65>$ & 0.64 & 0.60 & 1.06 & 4 \\
\hline$A_{4}$ & $<0.92,-0.24>$ & $<0.90,-0.61>$ & 0.84 & 0.64 & 1.30 & 1 \\
\hline
\end{tabular}

Table 9

THE FINAL RANKING ORDERS OBTAINED BY USING THE TOPSIS AND THE SAW METHODS

\begin{tabular}{|c|c|c|c|c|}
\hline \multirow{2}{*}{ Alternatives } & \multicolumn{2}{|c|}{ TOPSIS } & \multicolumn{2}{c|}{ SAW } \\
\cline { 2 - 5 } & $\mathbf{C}_{\mathbf{i}}$ & Rank & $\mathbf{S}_{\mathbf{i}}$ & Rank \\
\hline $\mathrm{A}_{1}$ & 0.527 & 1 & 0.646 & 2 \\
\hline $\mathrm{A}_{2}$ & 0.498 & 3 & 0.538 & 3 \\
\hline $\mathrm{A}_{3}$ & 0.488 & 4 & 0.531 & 4 \\
\hline $\mathrm{A}_{4}$ & 0.526 & 2 & 0.672 & 1 \\
\hline
\end{tabular}

method is caused by a very small difference in $C_{i}$ values of alternatives $A_{1}$ and $A_{4}$ that are 0.527 and 0.526 . Any slight change in the weight of the criteria or the ratings of the alternative probably would lead to the same ranking order of alternatives.

\section{CONCLUSION}

Information and communication technologies play a significant role in the processing of information and their transformation into knowledge, which is a basic condition for creating an information society. As stated before, green ICT as an area that is new and in development is directed towards establishing a balance between these technologies and the environment. Adoption of such technologies is a very complex and challenging task. In this paper, the application of bipolar fuzzy MULTIMOORA method is proposed for the evaluation of green ICT adoption in the textile industry. During the evaluation process, a total of three decision-makers (domain experts) were involved, who evaluated four alternatives. For the purpose of evaluation of alternatives, a total number of five criteria were used. When it comes to the determination of criteria, PIPRECA method was used, because of its simplicity and ease of use, especially when collecting attitudes from the experts who are not close with the MCDM methods. The final ranking of the alternatives was determined by applying the newly-developed bipolar fuzzy MULTIMOORA method. Alternative denoted as $A_{4}$ is the best in terms of evaluated criteria. Although the proposed method is relatively new, the same was an excellent choice for the given purpose. The proposed integrated approach that is based on the PIPRECIA and bipolar fuzzy MULTIMOORA method has proved to be easy, effective and applicable for the evaluation of green ICT adoption in the textile company.

Additionally, with the purpose of verification of the proposed approach, sensitivity analysis is conducted. The obtained results have confirmed adequacy and the applicability of the proposed approach. Also, the proposed MCDM approach could be used in other areas as well. As a direction for future research, the proposed model could be easily modified with additional criteria or sub-criteria, if needed. Besides, other methods for weights determination can be used as well, such as the fuzzy PIPRECIA method, the fuzzy AHP method, and the Plithogenic-CRITIC method.

\section{REFERENCES}

[1] Kokeza, G., Urošević, S., Strategic directions of the development of the textile and clothing industry in the Republic of Serbia, In: Tekstilna industrija, 2018, 66, 4, 69-78

[2] Lu, S., Mok, P.Y., Jin, X., A new design concept: $3 D$ to $2 D$ textile pattern design for garments, In: Computer-Aided Design, 2017, 89, 35-49

[3] Stanujkic, D., Karabasevic, D., Maksimovic, M., The application of information and communication technologies in the textile industry, In: International scientific conference Contemporary trends in the textile industry, Belgrade, 2018, 55-62

[4] Davison, C., Information technology and innovation in language education (Vol. 1), In: Hong Kong University Press, 2005

[5] Toomey, R., Schooling Issues Digest No 2: information and communication technology for teaching and learning, In: Commonwealth Department of Education, Science and Training, 2001

[6] Lloyd, M., Towards a definition of the integration of ICT in the classroom, In: AARE 2005lutions, Parramatta, New South Wales., AARE, Eds. Proceedings AARE, 5, 2005

[7] Mamun, S.A.K., Danaher, P.A., Rahman, M.M., University teachers' interactions with their online students at an Australian university, In: Blended learning: Concepts, methodologies, tools, and applications, IGI Global, 2017, 1565-1595 
[8] Tazhina, G., Regional University Partnership for Sustainable Development in the Age of Digital Technologies, In: Toward Sustainability Through Digital Technologies and Practices in the Eurasian Region, IGI Global, 2020, 152-174

[9] Veljović, A., Vulović, R., Damnjanović, A., Information and Communication Technologies in Management, In: Faculty of Technical Sciences Čačak, 2009

[10] Murray, J., Cloud network architecture and ICT-Modern network architecture, 2011, Available at: http://itknowledgeexchange.techtarget.com/modern-network-architecture/cloud-network-architecture-and-ict [Accessed January 2020]

[11] Din, N., Haron, S., Ahmad, H., The level of awareness on the green ICT concept and self directed learning among Malaysian Facebook users, In: Procedia-Social and Behavioral Sciences, 2013, 85, 464-473

[12] Reimsbach-Kounatze, C., Towards Green ICT Strategies: Assessing Policies and Programmes on ICT and the Environment, In: OECD Digital Economy Papers, 155, OECD Publishing, 2009, http://dx.doi.org/10.1787/ 222431651031

[13] Sarkis, J., Zhu, H., Information technology and systems in China's circular economy: implications for sustainability, In: Journal of Systems and Information Technology, 2008, 10, 3, 202-217

[14] Andreopoulou, Z., Green Informatics: ICT for green and Sustainability, In: Agrárinformatika/Journal of Agricultural Informatics, 2012, 3, 2, 1-8

[15] Radu, L.D., Determinants of green ICT adoption in organizations: a theoretical perspective, In: Sustainability, 2016, $8,8,731$

[16] Karabašević, D., Popović, G., Stanujkić, D., Maksimović, M., Sava, C., An approach for hotel type selection based on the single-valued intuitionistic fuzzy numbers, In: International Review, 2019, 1-2, 7-14

[17] Stanujkic, D., Karabasevic, D., Zavadskas, E.K., A New Approach for Selecting Alternatives Based on the Adapted Weighted Sum and the SWARA Methods: A Case of Personnel Selection, In: Economic Computation \& Economic Cybernetics Studies \& Research, 2017, 51, 3, 39-56

[18] Stanujkic, D., Popovic, G., Brzakovic, M., An approach to personnel selection in the IT industry based on the EDAS method, In: Transformations in Business \& Economics, 2018, 17, 2, 54-65

[19] Stanujkic, D., Zavadskas, E.K., Liu, S., Karabasevic, D., Popovic, G., Improved OCRA method based on the use of interval grey numbers, In: Journal of Grey System, 2017, 29, 4, 49-60

[20] Stanujkic, D., Zavadskas, E.K., Karabasevic, D., Urosevic, S., Maksimovic, M., An approach for evaluating website quality in hotel industry based on triangular intuitionistic fuzzy numbers, In: Informatica, 2017, 28, 4, 725-748

[21] Naeini, A.B., Mosayebi, A., Mohajerani, N., A hybrid model of competitive advantage based on Bourdieu capital theory and competitive intelligence using fuzzy Delphi and ism-gray Dematel (study of Iranian food industry), In: International Review, 2019, 1-2, 21-35

[22] Hassanpour, M., Pamucar, D., Evaluation of Iranian household appliance industries using MCDM models, In: Operational Research in Engineering Sciences: Theory and Applications, 2019, 2, 3, 1-25

[23] Ishizaka, A., Nemery, P., Multi-criteria decision analysis: methods and software, In: Wiley \& Sons, 2013

[24] Popovic, G., Stanujkic, D., Karabasevic, D., A framework for the evaluation of hotel property development projects, In: International Journal of Strategic Property Management, 2019, 23, 2, 96-107

[25] Stanujkic, D., Zavadskas, E.K., Karabasevic, D., Milanovic, D., Maksimovic, M., An approach to solving complex decision-making problems based on IVIFNs: A case of comminution circuit design selection, In: Minerals Engineering, 2019, 138, 70-78

[26] Stanujkic, D., Zavadskas, E.K., Karabašević, D., Turskis, Z., Kersuliene, V., New group decision-making ARCAS approach based on the integration of the SWARA and the ARAS methods adapted for negotiations, In: Journal of Business Economics and Management, 2017, 18, 4, 599-618

[27] Jauković Jocić, K., Karabašević, D., Jocić, G, The use of the PIPRECIA method for assessing the quality of elearning materials, In: Ekonomika, 2020, 66, 3

[28] Jauković Jocić, K., Karabašević, D., Popović, G., An approach for e-learning courses evaluation based on the EDAS method, In: Ekonomika, 2020, 66, 4

[29] Stanujkic, D., Karabasevic, D., Zavadskas, E.K., Smarandache, F., Brauers, W.K., A bipolar fuzzy extension of the MULTIMOORA method, In: Informatica, 2019, 30, 1, 135-152

[30] Brauers, W.K.M., Zavadskas, E.K., Project management by MULTIMOORA as an instrument for transition economies, In: Technological and Economic Development of Economy, 2010, 16, 1, 5-24

[31] Brauers, W.K.M., Optimization Methods for a Stakeholder Society, a Revolution in Economic Thinking by MultiObjective Optimization, In: Kluwer Academic Publishers, Boston, USA, 2004

[32] Brauers, W.K.M., Zavadskas, E.K., The MOORA method and its application to privatization in a transition economy, In: Control and Cybernetics, 2006, 35, 2, 445-469

[33] Brauers, W.K.M., Ginevicius, R., The economy of the Belgian regions tested with MULTIMOORA, In: Journal of Business Economics and Management, 2010, 11, 2, 173-209

[34] Fedajev, A., Stanujkic, D., Karabašević, D., Brauers, W.K., Zavadskas, E.K., Assessment of progress towards "Europe 2020" strategy targets by using the MULTIMOORA method and the Shannon Entropy Index, In: Journal of Cleaner Production, 2020, 244, 118895

[35] Karabasevic, D., Stanujkic, D., Urosevic, S., Maksimovic, M., Selection of candidates in the mining industry based on the application of the SWARA and the MULTIMOORA methods, In: Acta Montanistica Slovaca, 2015, 20, 2, 116-124

[36] Nabeeh, N.A., Abdel-Monem, A., Abdelmouty, A., A Hybrid Approach of Neutrosophic with MULTIMOORA in Application of Personnel Selection, In: Neutrosophic Sets and Systems, 2019, 30, 1-21 
[37] Baležentis, A., Baležentis, T., Brauers, W.K., Personnel selection based on computing with words and fuzzy MULTIMOORA, In: Expert Systems with applications, 2012, 39, 9, 7961-7967

[38] Baležentis, A., Baležentis, T., Brauers, W.K., MULTIMOORA-FG: a multi-objective decision making method for linguistic reasoning with an application to personnel selection, In: Informatica, 2012, 23, 2, 173-190

[39] Baležentis, A., Baležentis, T., An innovative multi-criteria supplier selection based on two-tuple MULTIMOORA and hybrid data, In: Economic Computation and Economic Cybernetics Studies and Research, 2011, 45, 2, 37-56

[40] Tavana, M., Shaabani, A., Mansouri Mohammadabadi, S., Varzgani, N., An integrated fuzzy AHP-fuzzy MULTIMOORA model for supply chain risk-benefit assessment and supplier selection, In: International Journal of Systems Science: Operations \& Logistics, 2020, 1-24

[41] Adalı, E.A., Işık, A.T., The multi-objective decision making methods based on MULTIMOORA and MOOSRA for the laptop selection problem, In: Journal of Industrial Engineering International, 2017, 13, 2, 229-237

[42] Chen, S.X., Wang, J.Q., Wang, T.L., Cloud-based ERP system selection based on extended probabilistic linguistic MULTIMOORA method and Choquet integral operator, In: Computational and Applied Mathematics, 2019, 38, 2, 88

[43] Liu, H.C., Zhao, H., You, X.Y., Zhou, W.Y., Robot evaluation and selection using the hesitant fuzzy linguistic MULTIMOORA method, In: Journal of Testing and Evaluation, 2019, 47, 2, 1405-1426

[44] Stanujkic, D., Zavadskas, E.K., Brauers, W.K.M., Karabašević, D., An Extension of the MULTIMOORA Method for Solving Complex Decision-Making Problems based on the Use of Interval-valued Triangular Fuzzy Numbers, In: Transformations in Business and Economics, 2015, 14, 2B (35B), 355-377

[45] Zhang, C., Chen, C., Streimikiene, D., Balezentis, T., Intuitionistic fuzzy MULTIMOORA approach for multi-criteria assessment of the energy storage technologies, In: Applied Soft Computing, 2019, 79, 410-423

[46] Shim, Y.H., Kim, K.Y., Cho, J.Y., Park, J.K., Lee, B.G., Strategic Priority of Green ICT Policy in Korea: Applying Analytic Hierarchy Process, In: World Academy of Science, Engineering and Technology, 2009, 58

[47] Masud, M.H., Malik, N.A., A strategic model for evaluating energy efficient ICT infrastructures for sustainable environment, In: J. Appl. Sci. Res, 2012, 8, 9, 4842-4853

[48] Stanujkic, D., Zavadskas, E.K., Karabašević, D., Smarandache, F., Turskis, Z., The use of Pivot Pair-wise Relative Criteria Importance Assessment method for determining weights of criteria, In: Romanian Journal of Economic Forecasting, 2017, 20, 4, 116-133

\author{
Authors: \\ DARJAN KARABASEVIC 1 , PAVLE RADANOV ${ }^{1}$, DRAGISA STANUJKIC², \\ GABRIJELA POPOVIC ${ }^{1}$, BRATISLAV PREDIC ${ }^{3}$ \\ ${ }^{1}$ University Business Academy in Novi Sad, Faculty of Applied Management, Economics and Finance, \\ Jevrejska 24, 11000, Belgrade, Serbia \\ e-mail: pavle.radanov@mef.edu.rs, gabrijela.popovic@mef.edu.rs \\ 2University of Belgrade, Technical faculty in Bor, VJ 12, 19210, Bor, Serbia \\ e-mail: dstanujkic@tfbor.bg.ac.rs \\ ${ }^{3}$ Faculty of Electronic Engineering, University of Niš, Aleksandra Medvedeva 14, 18000 Niš, Serbia \\ e-mail: bratislav.predic@elfak.ni.ac.rs
}

Corresponding author:

DARJAN KARABASEVIC

e-mail: darjan.karabasevic@mef.edu.rs; darjankarabasevic@gmail.com 